\title{
Cystathionine Beta-Synthase
}

National Cancer Institute

\section{Source}

National Cancer Institute. Cystathionine Beta-Synthase. NCI Thesaurus. Code C129051.

Cystathionine beta-synthase (551 aa, $\sim 61 \mathrm{kDa}$ ) is encoded by the human CBS gene. This protein plays a role in homocysteine metabolism. 